\title{
Macrocyclic cyclodiphosphazane $\left[\left\{\mathrm{P}\left(\mu-{ }^{t} \mathrm{BuN}\right)\right\}_{2}\left(\mathrm{O}-m-\mathrm{C}_{6} \mathrm{H}_{4}\right.\right.$ $\left.\left.\mathrm{CHNCH}_{2}\right)_{2}\right]_{2}$ : synthesis of chalcogen derivatives and gold(I) complex
}

\author{
VITTHALRAO S KASHID ${ }^{\mathrm{a}}$, JOEL T MAGUE ${ }^{\mathrm{b}}$ and MARAVANJI S BALAKRISHNA ${ }^{\mathrm{a}, *}$ \\ aPhosphorus Laboratory, Department of Chemistry, Indian Institute of Technology Bombay, Powai, \\ Mumbai 400 076, India \\ ${ }^{\mathrm{b}}$ Department of Chemistry, Tulane University, New Orleans, LA 70118, USA \\ E-mail: krishna@chem.iitb.ac.in; msb_krishna@iitb.ac.in
}

MS received 8 July 2017; revised 2 August 2017; accepted 6 August 2017; published online 6 September 2017

\begin{abstract}
The synthesis of a Schiff base-appended macrocycle $\left[\left\{\mathrm{P}\left(\mu{ }^{t} \mathrm{BuN}\right)\right\}_{2}\left(\mathrm{O}-m-\mathrm{C}_{6} \mathrm{H}_{4} \mathrm{CHNCH}_{2}\right)_{2}\right]_{2}$ (1) containing cyclodiphosphazane moieties is described. Reactions of $\mathbf{1}$ with $\mathrm{H}_{2} \mathrm{O}_{2}$ and elemental selenium yielded derivatives tetrakis(oxide) $\left[\left\{\mathrm{P}(\mathrm{O})\left(\mu-{ }^{t} \mathrm{BuN}\right)\right\}_{2}\left(\mathrm{O}-m-\mathrm{C}_{6} \mathrm{H}_{4} \mathrm{CHNCH}_{2}\right)_{2}\right]_{2}$ (2) and tetrakis(selenide) $\left[\left\{\mathrm{P}(\mathrm{Se})\left(\mu-{ }^{t} \mathrm{BuN}\right)\right\}_{2}\left(\mathrm{O}-m-\mathrm{C}_{6} \mathrm{H}_{4} \mathrm{CHNCH}_{2}\right)_{2}\right]_{2}(\mathbf{3})$, in $\sim 80 \%$ yield. Tetragold complex $\left[\mathrm{Au}_{4} \mathrm{Cl}_{4}\left\{\left\{\mathrm{P}\left(\mu-{ }_{-}{ }^{\mathrm{BuN}}\right)\right\}_{2}\left(\mathrm{O}-m-\mathrm{C}_{6} \mathrm{H}_{4} \mathrm{CHNCH}_{2}\right)_{2}\right\}_{2}\right]$ (4) was prepared by reacting 1 with $\left[\mathrm{AuCl}\left(\mathrm{SMe}_{2}\right)\right]$ in 1:4 molar ratio. All the compounds have been characterized by various spectroscopic techniques. The molecular structure of $\mathbf{3}$ was confirmed by single crystal $\mathrm{X}$-ray analysis.
\end{abstract}

Keywords. Cyclodiphosphazanes; chalcogen; selenide; macrocycle; gold(I).

\section{Introduction}

Cyclodiphosphazanes are the major class of saturated four-membered inorganic heterocycles containing phosphorus and nitrogen atoms arranged alternately with phosphorus in trivalent state. ${ }^{1-3}$ The dichlorocyclodiphosphazanes, cis- $\left[\{\mathrm{ClP}(\mu-\mathrm{NR})\}_{2}\right]$ are used as building blocks in the synthesis of a wide range of phosphorus-nitrogen macrocycles. ${ }^{4-10}$ Both main group and transition metal chemistry of cyclodiphosphazanes have been extensively studied in the last two decades. ${ }^{11-16}$ Many of these derivaives find applications in organometallic chemistry, macrocyclic chemistry, antitumor studies, ${ }^{17,18}$ chemical sensors, ${ }^{19}$ luminesence $^{20}$ and homogeneous catalysis. ${ }^{21-25}$ Recently cyclodiphosphazanes have been utilized in designing metal-organic frameworks with sodalite ${ }^{26}$ and diamon$\operatorname{doid}^{27}$ topoligies and also in biradical based small molecule activations. ${ }^{28-33}$

Cyclodiphosphazanes can exist as cis and trans isomers with respect to the exocyclic phosphorus substituents with a small energy difference in solution as well as in the solid state. ${ }^{34}$ Cis-trans isomerization in solution is very facile and leads to kinetically stable cis-isomers. ${ }^{35}$ Our group has extensively studied the transition metal chemistry and various applications of cyclodiphosphazanes. ${ }^{36-44}$ Herein, we report the synthesis of a macrocyclic Schiff base appended cyclodiphosphazane $\left[\left\{\mathrm{P}\left(\mu-^{t} \mathrm{BuN}\right)\right\}_{2}(\mathrm{O}-m-\right.$ $\left.\left.\mathrm{C}_{6} \mathrm{H}_{4} \mathrm{CHNCH}_{2}\right)_{2}\right]_{2}(\mathbf{1})$ and its tetrakis(oxide), tetrakis(selenide) derivatives and a tetragold complex.

\section{Experimental}

\subsection{General procedures}

All manipulations were performed using standard vacuumline and Schlenk techniques under nitrogen atmosphere unless otherwise stated. All the solvents were purified by conventional methods ${ }^{45}$ and distilled prior to use. The compounds, $c i s-\left[\mathrm{ClP}\left(\mu-\mathrm{N}^{t} \mathrm{Bu}\right)\right]_{2}{ }^{46}$ and $\left[\mathrm{AuCl}\left(\mathrm{SMe}_{2}\right)\right]^{47}$ were prepared according to the published procedures. $\mathrm{H}_{2} \mathrm{O}_{2}$ (30\% aq.) and elemental selenium were from Merck Life Science Pvt. Ltd, Mumbai, India and used as received. All other chemicals were obtained from commercial sources and purified prior to use.

\footnotetext{
*For correspondence
}

Electronic supplementary material: The online version of this article (doi:10.1007/s12039-017-1358-3) contains supplementary material, which is available to authorized users. 


\subsection{Instrumentation}

The NMR spectra were recorded at the following frequencies: $500 \mathrm{MHz}\left({ }^{1} \mathrm{H}\right), 202 \mathrm{MHz}\left({ }^{31} \mathrm{P}\right)$ and $125 \mathrm{MHz}\left({ }^{13} \mathrm{C}\right)$ using Bruker Avance-500 MHz spectrometer. The ${ }^{13} \mathrm{C}\left\{{ }^{1} \mathrm{H}\right\}$ and ${ }^{31} \mathrm{P}\left\{{ }^{1} \mathrm{H}\right\}$ NMR spectra were acquired using broad band proton decoupling. The spectra were recorded in $\mathrm{CDCl}_{3}$ solutions with $\mathrm{CDCl}_{3}$ as an internal lock; chemical shifts of ${ }^{1} \mathrm{H}$ and ${ }^{13} \mathrm{C}\left\{{ }^{1} \mathrm{H}\right\}$ NMR spectra are reported in ppm downfield from TMS, which was used as internal standard. The chemical shifts of ${ }^{31} \mathrm{P}\left\{{ }^{1} \mathrm{H}\right\}$ NMR spectra are referred to $85 \% \mathrm{H}_{3} \mathrm{PO}_{4}$ (in $\mathrm{D}_{2} \mathrm{O}$ ) used as external standard. The microanalyses were performed using a Carlo Erba Model 1112 elemental analyzer. Mass spectra were recorded on BRUKER mass spectrometer using Electro-spray ionization mass spectrometry (ESI-MS) method. The melting points were observed in capillary tubes and are uncorrected.

\subsection{Synthesis of $\left[\left\{P\left(\mu-{ }^{t} B u N\right)\right\}_{2}\left(O-m-C_{6} H_{4}\right.\right.$ $\left.\left.\mathrm{CHNCH}_{2}\right)_{2}\right]_{2}$ (1)}

To a well stirred mixture of $\left.\left[\mathrm{HO}-m-\mathrm{C}_{6} \mathrm{H}_{4} \mathrm{CHNCH}_{2}\right)\right]_{2}$ $(1 \mathrm{~g}, 3.72 \mathrm{mmol})$ and triethylamine $(1.04 \mathrm{~mL}, 7.45 \mathrm{mmol})$ in toluene $(50 \mathrm{~mL})$, a solution of $\left[{ }^{t} \mathrm{BuNPCl}\right]_{2}(1.02 \mathrm{~g}$, $3.72 \mathrm{mmol})$ also in toluene $(25 \mathrm{~mL})$ was added dropwise at $0{ }^{\circ} \mathrm{C}$ and the reaction mixture was allowed to warm to room temperature and then refluxed for $12 \mathrm{~h}$. The reaction mixture was filtered through celite and the solvent was evaporated under reduced pressure to give compound $\mathbf{1}$ as off-white solid. Recrystallization from a mixture of dichloromethane $(5 \mathrm{~mL})$ and petroleum ether $(3 \mathrm{~mL})$ at $10^{\circ} \mathrm{C}$ afforded analytically pure samples of 1 as colorless crystals. Yield 63\% (1.10 g). M.p.: 207-210 ${ }^{\circ} \mathrm{C}(\mathrm{dec})$. Anal. Calcd. for $\mathrm{C}_{48} \mathrm{H}_{66} \mathrm{O}_{4} \mathrm{~N}_{8} \mathrm{P}_{4} \cdot \mathrm{CH}_{2} \mathrm{Cl}_{2}$ : C, 61.43; H, 6.93; N, 11.91\%. Found: C, 61.29; H, 6.83; N, 11.64\%. HRMS (ESI): $m / z$ Calc. for $\mathrm{C}_{48} \mathrm{H}_{66} \mathrm{O}_{4} \mathrm{~N}_{8} \mathrm{P}_{4}(\mathrm{M}+\mathrm{H})$ : 943.4230, Found: 943.4156 . FT-IR (KBr disc) $\mathrm{cm}^{-1}: v_{C H}$ : 2961, 2930, 2863, $v_{C=N}: 2360,1641,1583,1458,1365$, $1238 \mathrm{s.}^{1} \mathrm{H}$ NMR $\left(400 \mathrm{MHz}, \mathrm{CDCl}_{3}\right): \delta 8.19(\mathrm{~s}, 4 \mathrm{H}, \mathrm{HC}=\mathrm{N})$, 7.52-7.05 (m, 16H, Ar-H), $3.86\left(\mathrm{~s}, 8 \mathrm{H}, \mathrm{H}_{2} \mathrm{CN}\right), 1.32(\mathrm{~s}$, $\left.36 \mathrm{H},{ }^{t} \mathrm{CH}_{3}\right)$ ppm. ${ }^{13} \mathrm{C}\left\{{ }^{1} \mathrm{H}\right\} \mathrm{NMR}\left(125 \mathrm{MHz}, \mathrm{CDCl}_{3}\right): 162.1$ $(\mathrm{HC}=\mathrm{N}), 153.7$ (Ar-C), 137.6 (Ar-C), $129.5(\mathrm{Ar}-\mathrm{C}), 129.3$ (Ar-C), 123.1 (Ar-C), 122.9 (Ar-C), 120.8 (Ar-C), 61.8 $\left(\mathrm{N}^{-} \mathrm{CH}_{2}\right), 31.4\left({ }^{t} \mathrm{C}\left(\mathrm{CH}_{3}\right)_{3}\right) \mathrm{ppm} .{ }^{31} \mathrm{P}\left\{{ }^{1} \mathrm{H}\right\}$ NMR $(202 \mathrm{MHz}$, $\left.\mathrm{CDCl}_{3}\right): \delta 138.3 \mathrm{ppm}$.

\subsection{Synthesis of $\left[\left\{P(O)\left(\mu{ }^{t} B u N\right)\right\}_{2}\left(O-m-C_{6} H_{4}\right.\right.$ $\left.\left.\mathrm{CHNCH}_{2}\right)_{2}\right]_{2}(2)$}

To a solution of $1(0.05 \mathrm{~g}, 0.053 \mathrm{mmol})$ in tetrahydrofuran $(15 \mathrm{~mL}), \mathrm{H}_{2} \mathrm{O}_{2}$ (30\% aq.) $(0.0144 \mathrm{~g}, 0.424 \mathrm{mmol})$ was added and the reaction mixture was stirred for $3 \mathrm{~h}$ at room temperature. After the volatiles were evaporated under reduced pressure, solid residue obtained was recrystallized from diethyl ether to give the analytically pure product of $\mathbf{2}$ as colorless crystalline solid. Yield 80\% (0.042 g). M.p.: 182$185{ }^{\circ} \mathrm{C}$ (dec). Anal. Calcd. for $\mathrm{C}_{48} \mathrm{H}_{66} \mathrm{O}_{4} \mathrm{~N}_{8} \mathrm{P}_{4} \mathrm{O}_{4} \cdot \mathrm{CH}_{2} \mathrm{Cl}_{2}$ :
C, 54.00; H, 6.10; N, 11.74\%. Found: C, 54.37; H, 6.52; $\mathrm{N}, 11.48 \%$. FT-IR (KBr disc) $\mathrm{cm}^{-1}: v_{\mathrm{CHN}}: 2965 \mathrm{~s}, 1698 \mathrm{~m}$, $v_{C=C}: 1585 \mathrm{~m}, 1482 \mathrm{~m}, 1448 \mathrm{~m}, v_{\mathrm{C}-\mathrm{H}}: 1372 \mathrm{~m}, v_{P=O}: 1262$ vs, $1091 \mathrm{vs}, 922 \mathrm{~s}, 800 \mathrm{vs} \mathrm{cm}^{-1} .{ }^{1} \mathrm{H}$ NMR $\left(500 \mathrm{MHz}, \mathrm{CDCl}_{3}\right)$ : $\delta 7.86(\mathrm{~s}, 4 \mathrm{H}, \mathrm{HC}=\mathrm{N}), 7.76-7.38(\mathrm{~m}, 16 \mathrm{H}, \mathrm{Ar}-\mathrm{H}), 3.75(\mathrm{~s}, 8 \mathrm{H}$, $\left.\mathrm{H}_{2} \mathrm{CN}\right), 1.47$ (s, $\left.36 \mathrm{H},{ }^{t} \mathrm{CH}_{3}\right) \mathrm{ppm} .{ }^{31} \mathrm{P}\left\{{ }^{1} \mathrm{H}\right\} \mathrm{NMR}(202 \mathrm{MHz}$, $\left.\mathrm{CDCl}_{3}\right): \delta-7.81(\mathrm{~s}) \mathrm{ppm}$.

\subsection{Synthesis of $\left[\left\{\mathrm{P}(\mathrm{Se})\left(\mu-^{t} \mathrm{BuN}\right)\right\}_{2}\left(\mathrm{O}-m-\mathrm{C}_{6} \mathrm{H}_{4}\right.\right.$ $\left.\left.\mathrm{CHNCH}_{2}\right)_{2}\right]_{2}(3)$}

This was synthesized by reacting $1(0.03 \mathrm{~g}, 0.031 \mathrm{mmol})$ with elemental selenium $(0.0195 \mathrm{~g}, 0.248 \mathrm{mmol})$ in toluene $(15 \mathrm{~mL})$ under refluxing condition for $12 \mathrm{~h}$. After completion of the reaction, the reaction mixture was filtered through celite. The solvent was removed under reduced pressure to afford $\mathbf{3}$ as off-white solid. Recrystallization from toluene/petroleum ether gave colorless crystals. Yield $78 \%$ (0.03 g). M.p.: $207-209{ }^{\circ} \mathrm{C}(\mathrm{dec})$. Anal. Calcd. for $\mathrm{C}_{48} \mathrm{H}_{66} \mathrm{O}_{4} \mathrm{~N}_{8} \mathrm{P}_{4} \mathrm{Se}_{4}$. toluene: $\mathrm{C}, 48.81 ; \mathrm{H}, 5.36 ; \mathrm{N}, 8.28 \%$. Found: C, 48.53; H, 4.93; N, 8.21\%. MS (ESI): $\mathrm{m} / \mathrm{z}$ Calc. for $\mathrm{C}_{48} \mathrm{H}_{64} \mathrm{~N}_{8} \mathrm{O}_{4} \mathrm{P}_{4} \mathrm{Se}_{4}(\mathrm{M}+\mathrm{H}): 1260.0661$, Found: 1261.0614. FT-IR (KBr disc) $\mathrm{cm}^{-1}: v_{\mathrm{CHN}}: 2967 \mathrm{~s}, 1943 \mathrm{~m}$, $1867 \mathrm{~m}, v_{\mathrm{C}=\mathrm{N}}: 1703 v_{\mathrm{C}=\mathrm{C}}: 1646 \mathrm{~s}, 1581 \mathrm{~s}, 1443 \mathrm{~s}, v_{\mathrm{C}-\mathrm{H}}$ : $1372 \mathrm{~m}, v_{\mathrm{P}=\mathrm{Se}}: 1259-1234$ (br) vs, $1049 \mathrm{~s}, 922 \mathrm{~s}, 894 \mathrm{~s} \mathrm{~cm}^{-1}$. 1H NMR (400 MHz, $\left.\mathrm{CDCl}_{3}\right): \delta 8.19(\mathrm{~s}, 4 \mathrm{H}, \mathrm{HC}=\mathrm{N}), 7.52$ 7.05 (m, 16H, Ar-H), 3.86 (s, 8H, $\left.\mathrm{H}_{2} \mathrm{CN}\right), 1.32$ (s, 36H, $\left.{ }^{t} \mathrm{CH}_{3}\right)$ ppm. ${ }^{31} \mathrm{P}\left\{{ }^{1} \mathrm{H}\right\}$ NMR $\left(202 \mathrm{MHz}, \mathrm{CDCl}_{3}\right): \delta 37.5(\mathrm{~s}$, $\left.{ }^{1} J_{\mathrm{SeP}}=982 \mathrm{~Hz}\right) \mathrm{ppm}$.

\subsection{Synthesis of $\left[A u_{4} C l_{4}\left\{\left\{P\left(\mu-{ }^{t} B u N\right)\right\}_{2}\left(O-m-C_{6}\right.\right.\right.$ $\left.\left.\left.\mathrm{H}_{4} \mathrm{CHNCH}_{2}\right)_{2}\right\}_{2}\right](4)$}

A solution of $\mathrm{AuCl}\left(\mathrm{SMe}_{2}\right)(0.037 \mathrm{~g}, 0.127 \mathrm{mmol})$ in dichloromethane $(5 \mathrm{~mL})$ was added to a solution of $\mathbf{1}(0.03 \mathrm{~g}$, $0.032 \mathrm{mmol})$ in the same solvent $(15 \mathrm{~mL})$ and the reaction mixture was stirred at room temperature for $6 \mathrm{~h}$ under dark. After the volatiles were removed under reduced pressure, the resulting off-white solid was crystallized from dichloromethane/petroleum ether. Yield 77\% (0.046 g). M.p.: 180-183 ${ }^{\circ} \mathrm{C}$ (dec). Anal. Calcd. for $\mathrm{C}_{48} \mathrm{H}_{66} \mathrm{O}_{4} \mathrm{~N}_{8} \mathrm{P}_{4} \mathrm{Au}_{4} \mathrm{Cl}_{4}$ : C, 30.82; H, 3.45; N, 5.99\%. Found: C, 31.37; H, 3.83; $\mathrm{N}, 6.24 \%$. MS (ESI): $\mathrm{m} / z$ Calc. for $\mathrm{C}_{48} \mathrm{H}_{64} \mathrm{Au}_{4} \mathrm{Cl}_{4} \mathrm{~N}_{8} \mathrm{O}_{4} \mathrm{P}_{4}$ $[\mathrm{M}-2 \mathrm{AuCl}+\mathrm{Na}]^{+}: 1427.2607$, Found: 1427.7053 . FT-IR (KBr disc) $\mathrm{cm}^{-1}: v_{\mathrm{CHN}}: 2972 \mathrm{~s}, 2586 \mathrm{~m}, 2487 \mathrm{~m}, 2034 \mathrm{~m}$, $1642 \mathrm{br}, \mathrm{s}, v_{\mathrm{C}=\mathrm{C}}: 1376 \mathrm{~m}, 1217 \mathrm{br}, \mathrm{s}, 1103 \mathrm{~m}, 917 \mathrm{~m} \mathrm{~cm}^{-1} \cdot{ }^{1} \mathrm{H}$ NMR $\left(500 \mathrm{MHz}, \mathrm{CDCl}_{3}\right): \delta 8.24(\mathrm{~s}, 4 \mathrm{H}, \mathrm{HC}=\mathrm{N}), 7.86$ $7.17(\mathrm{~m}, 16 \mathrm{H}, \mathrm{Ar}-\mathrm{H}), 3.86\left(\mathrm{~s}, 8 \mathrm{H}, \mathrm{H}_{2} \mathrm{C}=\mathrm{N}\right), 1.71(\mathrm{~s}, 36 \mathrm{H}$, $\left.{ }^{t} \mathrm{CH}_{3}\right) \quad \operatorname{ppm} .{ }^{31} \mathrm{P}\left\{{ }^{1} \mathrm{H}\right\} \quad \mathrm{NMR} \quad\left(202 \mathrm{MHz}, \quad \mathrm{CDCl}_{3}\right) \quad \delta$ $101.2 \mathrm{ppm}$.

\section{$2.7 \quad X$-ray crystallography}

A crystal of tetrakis(selenide) $\mathbf{3}$ suitable for single crystal X-ray analysis was mounted on a Cryoloop with a drop of Paratone oil and placed in the cold nitrogen stream of the 
<smiles>Oc1cccc(/C=N/CC/N=C/c2cccc(O)c2)c1</smiles>

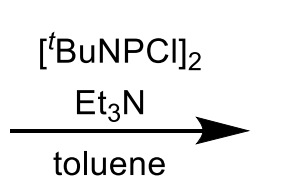

$\Delta, 12 \mathrm{~h}$

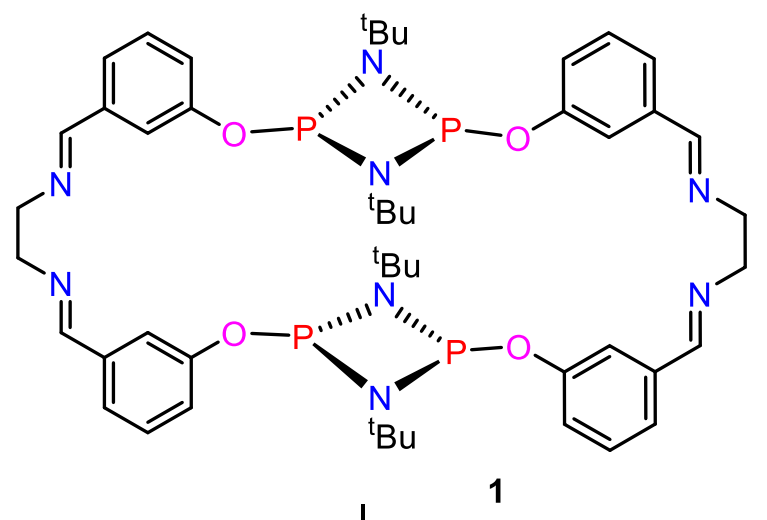

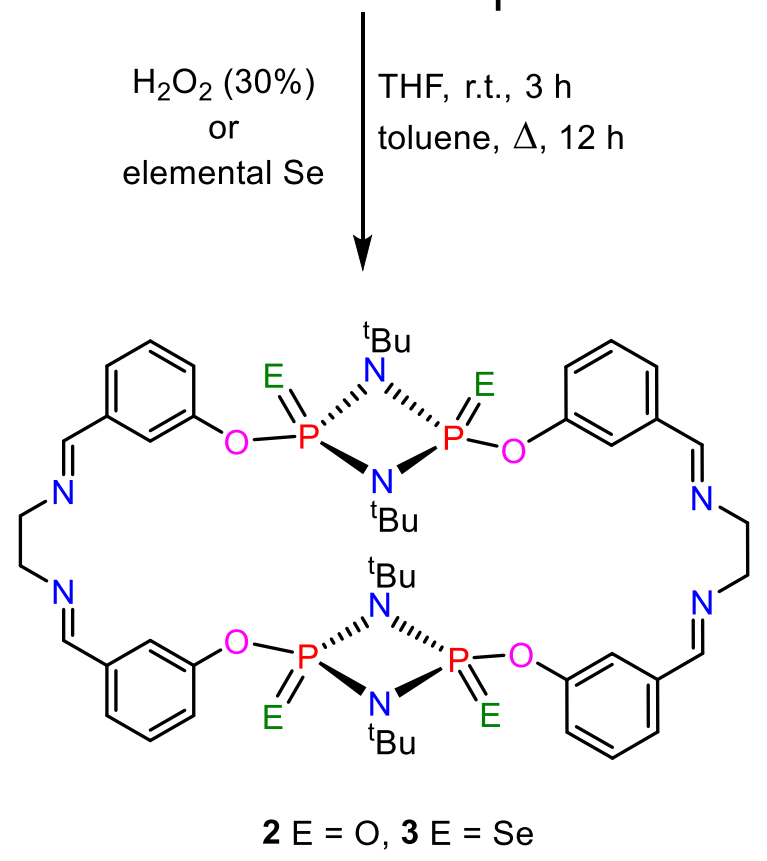

Scheme 1. Synthesis of $\mathbf{1}$ and its tetrakis(chalcogenides).

Kryoflex attachment of the Bruker APEX CCD diffractometer. A full sphere of data was collected using different sets of frames using the $A P E X 2^{48}$ program suite. For $\mathbf{3}$, the raw data were reduced to $\mathrm{F}^{2}$ values using the SAINT software. ${ }^{48}$ Multiple measurements of equivalent reflections provided the basis for an empirical absorption correction as well as a correction for any crystal deterioration during the data collection $\left(S A D A B S^{48}\right)$. The structure was solved by direct method $\left(S H E L X S^{49}\right)$ and refined by full-matrix least-squares procedures on $\mathrm{F}^{2}$ using SHELXL ${ }^{49}$ (SHELXTL program package $\left.{ }^{49}\right)$. Hydrogen atoms attached to carbon were placed in the calculated positions and included as riding contributions with isotropic displacement parameters tied to those of the attached non-hydrogen atoms. Those attached to nitrogens were placed in locations derived from a difference map and also included as riding contributions as for the others. Crystallographic data (including structures factors) for the structures reported in this paper have been deposited with the Cambridge Crystallographic Data Centre as supplementary publication no. CCDC No. 1560989 (Compound 3).

\section{Results and Discussion}

\subsection{Synthesis of 1 and its tetrakis(chalcogenides)}

The reaction of dichlorocyclodiphosphazane $\left(\left[{ }^{t} \mathrm{BuNPCl}\right]_{2}\right)$ with an equimolar amount of $[\mathrm{HO}-m-$ $\left.\mathrm{C}_{6} \mathrm{H}_{4} \mathrm{CHNCH}_{2}\right]_{2}$ (3, 3'-((1E,1'E)-(ethane-1,2-diylbis(azanylylidene))bis-(methanylylidene))diphenol) in the presence of triethylamine in toluene under refluxing condition yielded a macrocyclic compound $\left[\left\{\mathrm{P}\left(\mu-^{t}\right.\right.\right.$ $\left.\mathrm{BuN})\}_{2}\left(\mathrm{O}-m-\mathrm{C}_{6} \mathrm{H}_{4} \mathrm{CHNCH}_{2}\right)_{2}\right]_{2}$ (1) as shown in Scheme 1. The ${ }^{31} \mathrm{P}\left\{{ }^{1} \mathrm{H}\right\}$ NMR spectrum of $\mathbf{1}$ showed a single resonance at $138.3 \mathrm{ppm}$ and the mass spectrum showed $\mathrm{m} / z$ ion peak for $[\mathrm{M}+\mathrm{H}]^{+}$at 943.4156 depicting a dimeric structure.

Treatment of 1 with $\mathrm{H}_{2} \mathrm{O}_{2}$ (30\%) or elemental selenium resulted in the formation of tetrachalcogenides, $\left[\left\{\mathrm{P}(\mathrm{O})\left(\mu-{ }^{t} \mathrm{BuN}\right)_{2}\right\}_{2}\left(\mathrm{O}-m-\mathrm{C}_{6} \mathrm{H}_{4} \mathrm{CHNCH}_{2}\right)_{2}\right]_{2}$ (2) and $\left[\left\{\mathrm{P}(\mathrm{Se})\left(\mu-{ }^{t} \mathrm{BuN}\right)_{2}\right\}_{2}\left(\mathrm{O}-m-\mathrm{C}_{6} \mathrm{H}_{4} \mathrm{CHNCH}_{2}\right)_{2}\right]_{2}$ 


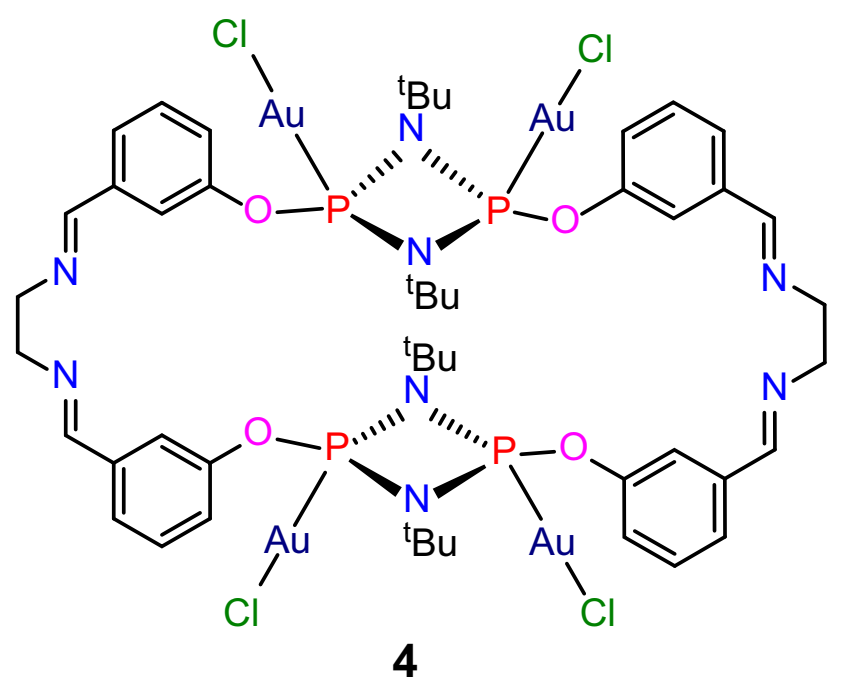

Figure 1. Tetragold complex 4.
(3), respectively. The ${ }^{31} \mathrm{P}\left\{{ }^{1} \mathrm{H}\right\}$ NMR spectra of 2 and 3 showed single resonances at -7.8 and $37.5 \mathrm{ppm}$, respectively. The tetrakis(selenide) showed characteristic ${ }^{77}$ Se satellites with a large ${ }^{1} J_{P S e}$ coupling of $982 \mathrm{~Hz}$. The phosphorus chemical shifts indicate the symmetric nature of the molecule with all phosphorus atoms being magnetically equivalent. ${ }^{1} \mathrm{H}$ NMR data is consistent with the structures proposed for 1-3. Attempts to grow crystals of $\mathbf{1}$ suitable for single crystal X-ray analysis have been unsuccessful. However, the structure of tetrakis(selenide) $\mathbf{3}$ was confirmed by single crystal Xray analysis.

The reaction of $\mathbf{1}$ with four equivalents of [AuCl $\left.\left(\mathrm{SMe}_{2}\right)\right]$ in dichloromethane afforded a tetragold derivative $\left[\left(\mathrm{Au}_{4} \mathrm{Cl}_{4}\right)\left\{\left\{\mathrm{P}\left(\mu-{ }^{t} \mathrm{BuN}\right)\right\}_{2}\left(O-m-\mathrm{C}_{6} \mathrm{H}_{4} \mathrm{CHNCH}_{2}\right.\right.\right.$ $\left.\left.-)_{2}\right\}_{2}\right]$ (4) in $77 \%$ yield (Figure 1). The ${ }^{31} \mathrm{P}\left\{{ }^{1} \mathrm{H}\right\}$ NMR spectrum of complex 4 showed a single resonance at
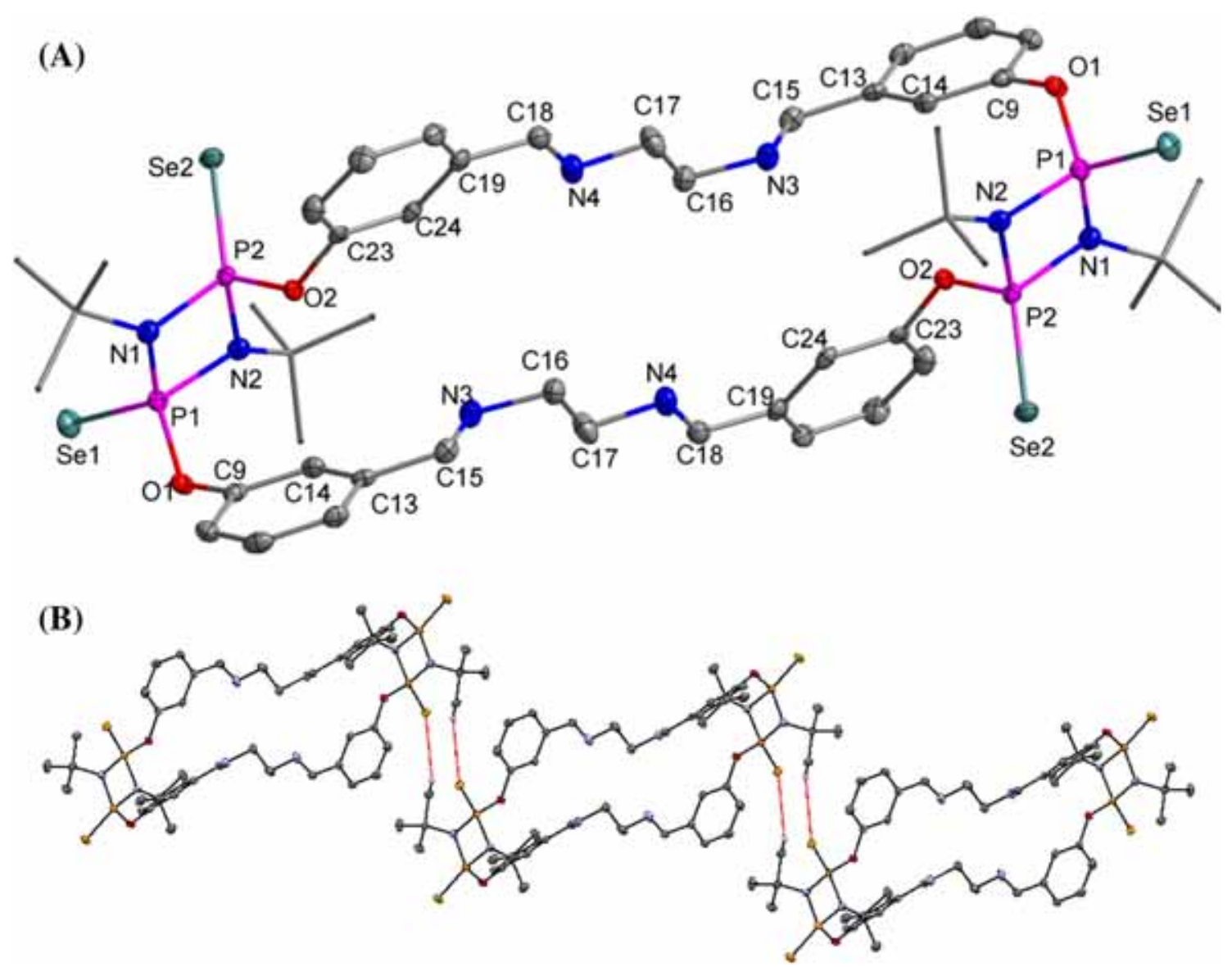

Figure 2. (A) Molecular structure of $\left[\left\{\mathrm{P}(\mathrm{Se})\left(\mu{ }^{-}{ }^{t} \mathrm{BuN}\right)\right\}_{2}\left(\mathrm{O}-m-\mathrm{C}_{6} \mathrm{H}_{4} \mathrm{CHNCH}_{2}\right)_{2}\right]_{2}$ (3). (B) The core of $1 \mathrm{D}$ polymeric structure of $\mathbf{3}$ showing Se-H-C interactions. All hydrogen atoms have been omitted for clarity. Thermal ellipsoids are drawn at the $50 \%$ probability level. Selected bond distances $(\AA)$ and bond angles $\left({ }^{\circ}\right): \mathrm{Se} 1-\mathrm{P} 1=2.067(2), \mathrm{P} 1-\mathrm{O} 1=1.600(5), \mathrm{P} 1-\mathrm{N} 1=1.673(6), \mathrm{P} 1-\mathrm{P} 2=2.488 \mathrm{O} 1-\mathrm{P} 1-\mathrm{N} 1=108.9(3)$, $\mathrm{O} 1-\mathrm{P} 1-\mathrm{N} 2=110.2(3), \mathrm{N} 2-\mathrm{P} 1-\mathrm{N} 1=84.4(3), \mathrm{N} 1-\mathrm{P} 1-\mathrm{Se} 1=122.5(2)$. 
101.2 ppm and the mass spectrum showed $\mathrm{m} / \mathrm{z}$ ion peak for $[\mathrm{M}-2 \mathrm{AuCl}+\mathrm{Na}]^{+}$at 1427.7053 .

\subsection{Molecular structure of 3}

The molecular structure of $\mathbf{3}$ was confirmed by single crystal X-ray analysis. The slow evaporation of petroleum ether into the saturated solution of $\mathbf{3}$ in dichloromethane afforded crystals suitable for single crystal X-ray study. The cyclodiphophazane moieties adopted cis-conformation, whereas the Schiff's base linker adopted trans-conformation with respect to the ethylenediamine linkers. All four selenium atoms are projected exterior to the molecule. The macrocyclic compound $\mathbf{3}$ is centrosymmetric with puckered conformation as shown in Figure 2. The molecule exhibits one dimensional polymeric structure due to the intermolecular interaction between selenium atoms and $\mathrm{C}-\mathrm{H}$ of one of the tertiary butyl groups of $\mathrm{N}_{2} \mathrm{P}_{2}$ ring on both sides with Se-H-C angle of $139.9^{\circ}$.

\section{Conclusions}

A new Schiff base appended dimeric cyclodiphosphazane derivtive $\left[\left\{\mathrm{P}\left(\mu-{ }^{t} \mathrm{BuN}\right)\right\}_{2}\left(\mathrm{O}-m-\mathrm{C}_{6} \mathrm{H}_{4} \mathrm{CHNCH}_{2}\right)_{2}\right]_{2}$ (1) was synthesized by reacting dichlorocyclodiphosphazane with 3, 3'-((1E,1'E)-(ethane-1,2-diylbis(azanylylidene))bis-(methanylylidene))diphenol. Compound 1 readily reacts with $\mathrm{H}_{2} \mathrm{O}_{2}$ and $\mathrm{Se}_{8}$ to give the corresponding tetrachalcogenides. The tetragold complex 4 was obtained by reacting 1 with four equivalents of $\left[\mathrm{AuCl}\left(\mathrm{SMe}_{2}\right)\right]$. The molecular structure of tetraselenide was established by single crystal X-ray analysis. Four selenium atoms are projected exterior from the macrocyclic unit making it an ideal ligand for moderately soft transition elements as well as lanthanides. Presently we are exploring the utility of compound $\mathbf{1}$ and its tetrachalcogenides to synthesize 2D- and 3D-coordination polymers and metal organic frameworks.

\section{Supplementary Information (SI)}

NMR and IR spectra for compounds 1-4 and crystallographic data for $\mathbf{3}$ are provided at www.ias.ac.in/chemsci. Crystallographic data for compounds $\mathbf{3}$ has been deposited at the Cambridge Crystallographic Data Centre with CCDC no.1560989 (Compound 3). These data can be obtained free of charge at www.ccdc.cam.ac.ul/conts/retrieving.html [or from the Cambridge Crystallographic Data Centre (CCDC), 12 Union Road, Cambridge CB2 1EZ, UK; fax: +44(0)1223336033; E-mail: deposit@ccdc.cam.ac.uk].

\section{Acknowledgements}

This work was supported by a Grant SB/S1/IC-108/2014 from Science \& Engineering Research Board (SERB), New Delhi, India. VSK thanks UGC, New Delhi for Senior Research Fellowship (SRF) and IRCC for financial support. We also thank the Department of Chemistry and Instrumentation Facilities, IIT Bombay, for spectral and analytical data. JTM thanks the Louisiana Board of Regents for the purchase of the CCD diffractometer and the Chemistry Department of Tulane University for support of the X-ray laboratory.

\section{References}

1. Balakrishna M S, Eisler D J and Chivers T 2007 Chemistry of pnictogen(III)-nitrogen ring systems Chem. Soc. Rev. 36650

2. Stahl L 2000 Bicyclic and tricyclic bis(amido)cyclodiphosph(III)azane compounds of main group elements Coord. Chem. Rev. 210203

3. Balakrishna M S 2016 Cyclodiphosphazanes: options are endless Dalton Trans. 4512252

4. Ananthnag G S, Kuntavalli S, Mague J T and Balakrishna M S 2012 Resorcinol based acyclic dimeric and cyclic di- and tetrameric cyclodiphosphazanes: Synthesis, structural studies, and transition metal complexes Inorg. Chem. 515919

5. Nordheider A, Chivers T, Thirumoorthi R, Vargas-Baca I and Woollins J D 2012 Planar $\mathrm{P}_{6} \mathrm{E}_{6}(\mathrm{E}=\mathrm{Se}, \mathrm{S})$ macrocycles incorporating $\mathrm{P}_{2} \mathrm{~N}_{2}$ scaffolds Chem. Commun. 48 6346

6. Calera S G and Wright D S 2010 Macrocyclic phosphazane ligands Dalton Trans. 395055

7. Gonzalez-Calera S, Eisler D J, Morey J V, McPartlin M, Singh S and Wright D S 2008 The Selenium-Based Hexameric Macrocycle $\left[(\mathrm{Se}) \mathrm{P}\left(\mu-\mathrm{N}^{t} \mathrm{Bu}\right)_{2} \mathrm{P}(\mu-\mathrm{Se})\right]_{6}$ Angew. Chem. Int. Ed. 471111

8. Dodds F, Garcia F, Kowenicki R A, McPartlin M, Steiner A and Wright D S 2005 Synthesis and structure of the calixarene-like phosph(III)azane macrocycle $[\mathrm{P}(\mu$ $\left.\left.\left.\mathrm{N}^{t} \mathrm{Bu}\right)\right\}_{2}\left\{1,5-(\mathrm{NH})_{2} \mathrm{C}_{10} \mathrm{H}_{6}\right\}\right]_{3}$ Chem. Commun. 3733

9. Chakravarty M, Kommana P and Kumara Swamy K C 2005 Non-stoichiometry induced by differential oxygen/lone pair occupation in chiral bicyclic 1,1[prime or minute]-binaphthoxy cyclodiphosphazanes Chem. Commun. 5396

10. Kommana P and Kumara Swamy K C 2000 Synthesis and Structural Characterization of a New Class of Macrocycles Based on a Cyclodiphosphazane Skeleton Inorg. Chem. 394384

11. Rastatter M, Muterle R B, Roesky P W and Thiele S K H 2009 Bis(amido)cyclodiphosph(III)azane Complexes of Yttrium and the Lanthanides Chem. Eur. J. 15474

12. Chandrasekaran P, Mague J T and Balakrishna M S 2006 Copper(I) coordination polymers $\left[\{\mathrm{Cu}(\mu-\mathrm{X})\}_{2}\{\mathrm{RP}(\mu-\right.$ $\left.\left.\left.\mathrm{N}^{t} \mathrm{Bu}\right)\right\}_{2}\right]_{\mathrm{n}}\left(\mathrm{R}=\mathrm{OC}_{6} \mathrm{H}_{4} \mathrm{OMe}-\mathrm{o} ; \mathrm{X}=\mathrm{Cl}, \mathrm{Br}\right.$, and $\left.\mathrm{I}\right)$ and their reversible conversion into mononuclear complexes $\left.\left[\mathrm{CuX}\left(\mathrm{RP}\left(\mu-\mathrm{N}^{t} \mathrm{Bu}\right)\right)_{2}\right\}_{2}\right]$ : Synthesis and structural characterization Inorg. Chem. 456678 
13. Schranz I, Lief G R, Carrow C J, Haagenson D C, Grocholl L, Stahl L, Staples R J, Boomishankar R and Steiner A 2005 Reversal of polarization in amidophosphines: neutral- and anionic- $\kappa P$ coordination vs. anionic- $\kappa P, N$ coordination and the formation of nickelaazaphosphiranes Dalton Trans. 3307

14. Bond A D, Doyle E L, Garcia F, Kowenicki R A, McPartlin M, Riera L and Wright D S 2003 Exo-metal coordination by a tricyclic $\quad\left[\left\{\mathrm{P}\left(\mu-\mathrm{N}-2-\mathrm{NC}_{5} \mathrm{H}_{4}\right)\right\}_{2}(\mu-\mathrm{O})\right]_{2}$ dimerin $\left[\left\{\mathrm{P}\left(\mu-\mathrm{N}-2-\mathrm{NC}_{5} \mathrm{H}_{4}\right)\right\}_{2}(\mu-\mathrm{O})\right]_{2} \mathrm{CuCl}$. $\left.\left(\mathrm{C}_{5} \mathrm{H}_{5} \mathrm{~N}\right)_{2}\right\}_{4}\left(2-\mathrm{NC}_{5} \mathrm{H}_{4}=2-\right.$ pyridyl, $\mathrm{C}_{5} \mathrm{H}_{5} \mathrm{~N}=$ pyridine) Chem. Commun. 2990

15. Lief G R, Carrow C J, Stahl L and Staples R J 2001 Mono- and di-nickellaazaphosphiranes of monoand bis(amido)cyclodiphosph(III)azanes Chem. Commun. 1562

16. Grocholl L, Stahl L and Staples R J 1997 Synthesis and single-crystal $\mathrm{X}$-ray structures of $\left[\left(\mathrm{Bu}^{t} \mathrm{NP}\right)_{2}\left(\mathrm{Bu}^{t} \mathrm{~N}\right)_{2}\right] \mathrm{MCl}_{2} \quad(\mathrm{M}=\mathrm{Zr}, \mathrm{Hf})$ : the first transition-metal bis(alkylamido)cyclodiphosphazane complexes Chem. Commun. 1465

17. Balakrishna M S, Suresh D, Rai A, Mague J T and Panda D 2010 Dinuclear copper(I) complexes containing cyclodiphosphazane derivatives and pyridyl ligands: Synthesis, structural studies, and antiproliferative activity toward human cervical and breast cancer cells Inorg. Chem. 498790

18. Suresh D, Balakrishna M S, Rathinasamy K, Panda D and Mobin S M 2008 Water-soluble cyclodiphosphazanes: Synthesis, gold(i) metal complexes and their in vitro antitumor studies Dalton Trans. 2812

19. Kreno L E, Leong K, Farha O K, Allendorf M, Van Duyne R P and Hupp J T 2012 Metal-Organic Framework Materials as Chemical Sensors Chem. Rev. 1121105

20. Cui Y, Yue Y, Qian G and Chen B 2012 Luminescent Functional Metal-Organic Frameworks Chem. Rev. 112 1126

21. Axenov K V, Kotov V V, Klinga M, Leskelä M and Repo T 2004 New Bulky Bis(amino)cyclodiphosph(III)azanes and Their Titanium(IV) Complexes: Synthesis, Structures and Ethene Polymerization Studies Eur. J. Inorg. Chem. 695

22. Axenov $\mathrm{K} \quad \mathrm{V}, \quad$ Klinga $\mathrm{M}$, Leskela M, Kotov V and Repo T 2004 [Bis(amido)cyclodiphosph(III)azane]dichlorozirconium Complexes for Ethene Polymerization Eur. J. Inorg. Chem. 4702

23. Roth T, Wadepohl H, Wright D S and Gade L H 2013 Chiral Ditopic Cyclophosphazane (CycloP) Ligands: Synthesis, Coordination Chemistry, and Application in Asymmetric Catalysis Chem. Eur. J. 1913823

24. Ananthnag G S, Mague J T and Balakrishna M S 2015 Self-Assembled Cyclophane-Type Copper(I) Complexes of 2,4,6-Tris(diphenylphosphino)-1,3,5-triazine and Their Catalytic Application Inorg. Chem. 5410985

25. Ananthnag G S, Mague J T and Balakrishna M S 2015 A cyclodiphosphazane based pincer ligand, [2, 6$\left.\left\{\mu-\left({ }^{t} \mathrm{BuN}\right)_{2} \mathrm{P}\left({ }^{t} \mathrm{BuHN}\right) \mathrm{PO}\right\}_{2} \mathrm{C}_{6} \mathrm{H}_{3} \mathrm{I}\right]: \mathrm{Ni}(\mathrm{II}), \mathrm{Pd}(\mathrm{II}), \mathrm{Pt}(\mathrm{II})$ and $\mathrm{Cu}(\mathrm{I})$ complexes and catalytic studies Dalton Trans. 443785
26. Siddiqui M M, Mobin S M, Senkovska I, Kaskel S and Balakrishna M S 2014 Novel zeotype frameworks with soft cyclodiphosphazane linkers and soft $\mathrm{Cu}_{4} \mathrm{X}_{4}$ clusters as nodes Chem. Commun. 5012273

27. Siddiqui M M, Mague J T and Balakrishna M S 2015 Diamondoid-Type Copper Coordination Polymers Containing Soft Cyclodiphosphazane Ligands Inorg. Chem. 546063

28. Beweries T, Kuzora R, Rosenthal U, Schulz A and Villinger A $2011[\mathrm{P}(\mu \text {-NTer })]_{2}$ : A Biradicaloid That Is Stable at High Temperature Angew. Chem. Int. Ed. 50 8974

29. Hering C, Schulz A and Villinger A 2012 LowTemperature Isolation of An Azidophosphenium Cation Angew. Chem. Int. Ed. 516241

30. Hinz A, Schulz A and Villinger A 2014 New P-N Cage Compounds Generated by Small-Molecule Activation Chem. Eur. J. 203913

31. Hinz A, Schulz A and Villinger A 2015 Stable Heterocyclopentane-1,3-diyls Angew. Chem. Int. Ed. 54 2776

32. Hinz A, Schulz A and Villinger A 2015 Tunable Cyclopentane-1,3-diyls Generated by Insertion of Isonitriles into Diphosphadiazanediyls J. Am. Chem. Soc. 137 9953

33. Mayer P, Schulz A and Villinger A $2007 \mathrm{GaCl}_{3}$-assisted [3 + 2] cycloaddition: A route to new binary PNheterocycles J. Organomet. Chem. 6922839

34. Stahl L 2000 Bicyclic and tricyclic bis(amido)cyclodiphosph(III)azane compounds of main group elements Coord. Chem. Rev. 210203

35. Silaghi-Dumitrescu I, Lara-Ochoa F and Haiduc I 1998 Edge or Verte Inversion at Phosphorus in the cis-trans Isomerization of Diazadiphosphetidines? Model MNDO and ab initio Molecular Orbital Calculations Main Group Chem. 2309

36. Balakrishna M S, Reddy V S, Krishnamurthy S S, Nixon J F and Laurent J C T R B S 1994 Coordination chemistry of diphosphinoamine and cyclodiphosphazane ligands Coord. Chem. Rev. 1291

37. Chandrasekaran $\mathrm{P}$, Mague $\mathrm{J} \mathrm{T}$ and Balakrishna M S 2005 Tetranuclear Rhodium(I) Macrocycle Containing Cyclodiphosphazane $\left[\mathrm{Rh}_{2}(\mu-\mathrm{Cl})_{2}(\mathrm{CO})_{2}\left[\left({ }^{t} \mathrm{BuNP}\left(\mathrm{OC}_{6} \mathrm{H}_{4} \mathrm{OMe}-\mathrm{O}\right)\right)_{2}\right.\right.$ $\kappa \mathrm{P}]]_{2}$ and Its Reversible Conversion into trans-[Rh(CO) Cl $\left\{\left({ }^{t} \mathrm{BuNP}\left(\mathrm{OC}_{6} \mathrm{H}_{4} \mathrm{OMe}-\mathrm{O}\right)\right)_{2}\right.$ $\kappa \mathrm{P}\}_{2}$ ] Organometallics 243780

38. Chandrasekaran P, Mague J T and Balakrishna M S 2005 Cyclodiphosphazanes with Hemilabile Ponytails: Synthesis, Transition Metal Chemistry (Ru(II), Rh(I), $\mathrm{Pd}(\mathrm{II}), \mathrm{Pt}(\mathrm{II}))$, and Crystal and Molecular Structures of Mononuclear (Pd(II), Rh(I)) and Bi- and Tetranuclear Rhodium(I) Complexes Inorg. Chem. 447925

39. Chandrasekaran P, Mague J T and Balakrishna M S 2006 Intramolecular Amine-Induced [1,3]-Sigmatropic Rearrangement in the Reactions of Aminophosphinites or Phosphites with Elemental Sulfur or Selenium Inorg. Chem. 455893

40. Balakrishna M S, Chandrasekaran P and Venkateswaran R 2007 Functionalized cyclodiphosphazanes cis$\left[{ }^{t} \mathrm{BuNP}(\mathrm{OR})\right]_{2} \quad\left(\mathrm{R}=\mathrm{C}_{6} \mathrm{H}_{4} \mathrm{OMe}-\mathrm{O}, \mathrm{CH}_{2} \mathrm{CH}_{2} \mathrm{OMe}\right.$, 
$\mathrm{CH}_{2} \mathrm{CH}_{2} \mathrm{SMe}, \mathrm{CH}_{2} \mathrm{CH}_{2} \mathrm{NMe}_{2}$ ) as neutral $2 \mathrm{e}, 4 \mathrm{e}$ or $8 \mathrm{e}$ donor ligands J. Organomet. Chem. 6922642

41. Chandrasekaran P, Mague J T and Balakrishna M S 2007 One-dimensional silver(I) coordination polymers containing cyclodiphosphazane, $c i s-\left\{\left(\mathrm{o}-\mathrm{MeOC}_{6} \mathrm{H}_{4} \mathrm{O}\right) \mathrm{P}(\mu-\right.$ $\left.\left.\mathrm{N}^{t} \mathrm{Bu}\right)\right\}_{2}$ Dalton Trans. 2957

42. Suresh D, Balakrishna M S and Mague J T 2008 Novel octanuclear copper(I) metallomacrocycles and their transformation intohexanuclear 2-dimensional grids of copper(I) coordination polymerscontaining cyclodiphosphazanes, $\left[\left(\mu-\mathrm{N}^{t} \mathrm{BuP}\right)_{2}\left(\mathrm{NC}_{4} \mathrm{H}_{8} \mathrm{X}\right)_{2}\right]$ (X = NMe, O) Dalton Trans. 3272

43. Chandrasekaran $\mathrm{P}$, Mague $\mathrm{J} T$ and Balakrishna M S 2009 Gold(I) complexes of cyclodiphosphazanes $\quad \operatorname{cis}-\left\{\mathrm{RP}\left(\mu-\mathrm{N}^{t} \mathrm{Bu}\right)\right\}_{2}$ : structure of a novel tetranuclear gold(I) macrocycle, $\left[\left\{\mathrm{Au}\left\{\left(\mathrm{o}-\mathrm{MeOC}_{6} \mathrm{H}_{4} \mathrm{O}\right) \mathrm{P}\left(\mu-\mathrm{N}^{\mathrm{t}} \mathrm{Bu}\right)\right\}_{2}\right\}_{4}\right]\left(\mathrm{ClO}_{4}\right)_{4}$

Dalton Trans. 5478
44. Balakrishna M S, Venkateswaran R and Mague J T 2010 Transition metal chemistry of cyclodiphosphanes containing phosphine and amide-phosphine functionalities: Formation of a stable dipalladium(II) complex containing a Pd-P $\sigma$-bond Dalton Trans. 3911149

45. Armarego W L and Perrin D D 1996 In Purification of Laboratory Chemicals 4th edn. (Oxford: ButterworthHeinemann Linacre House, Jordan Hill)

46. Bashall A, Doyle E L, Tubb C, Kidd S J, McPartlin M, Woods A D and Wright D S 2001 The tetrameric macrocycle $\left[\left\{\mathrm{P}\left(\mu-\mathrm{N}^{t} \mathrm{Bu}\right)\right\}_{2} \mathrm{NH}\right]_{4}$ Chem. Commun. 2542

47. Brandys M-C, Jennings M C and Puddephatt R J 2000 Luminescent gold(I) macrocycles with diphosphine and 4,4'-bipyridyl ligands J. Chem. Soc., Dalton Trans. 4601

48. Bruker-AXS, SAINT +, Version 7.03, Madison, WI, 2006

49. Sheldrick G W 2008 SHELXL and SHELXS Acta Cryst. A64 112 